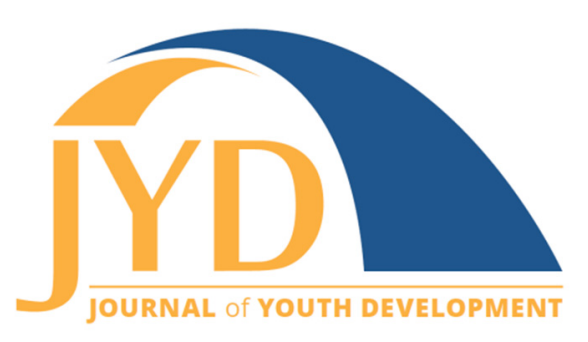

http://jyd.pitt.edu/ | Vol. 13 Issue 1-2 DOI 10.5195/jyd.2018.565 | ISSN 2325-4017 (online)

\title{
Welcome to the Bubble: Experiences of Liminality and Communitas among Summer Camp Counsellors
}

\author{
Mandi Baker \\ Blue Mountains International Hotel Management School, Torrens University \\ mandi.baker@laureate.edu.au
}

\begin{abstract}
Summer camps provide a special time and space for youth growth and transformation. This growth is possible, in part, due to the physical and social isolation that contribute to the liminality of traditional residential camps. Camps act as a sort of 'bubble' in which alternative realities, norms and identities emerge. For many campers and camp counsellors, the community and personal relationships that develop at camp produce feelings of acceptance and belonging. Positive camp experiences do not occur by happenstance and as such, youthful camp counsellors often feel immense pressure to deliver on the promises that camps offer. This article explores the challenges faced by counsellors as they seek to create and maintain this liminal space. This paper discusses camp counsellors' own reflections on their personal struggles with social isolation and the need to be accepted, effects of gossip in the close-knit community of camp, a lack of private time or space, and the emotional demands of caring for campers. The article concludes by suggesting how we might reconsider camp counsellor experiences and offers strategies to support counsellors as they navigate and negotiate camp experiences for both themselves and their campers.
\end{abstract}

Key words: summer camp, youth employment, liminality, community, emotional demands

\section{Arriving at Camp}

It's a farm road. I can't remember if it's paved or gravel or just dirt, but you know the kind... Trees line both sides: big old maples and oaks. Camp waited at the far end of the road. In my memories of the drive into camp, the trees are always green. I seem to remember we passed a dairy on the way in but most of this is blurry in my memory until the camp sign, "A sacred meeting place. "It's like this space has been marked the University of Pittsburgh Press. The Journal of Youth Development is the official peer-reviewed publication of the National Association of Extension 4-H Agents and the National AfterSchool Association. 


\section{Welcome to the Bubble}

out as special. The volume on my feelings gets turned up as I enter. I know this place is special-I just do. I feel just a little more connected here. Connected to what? I don't entirely know. Maybe nature? Maybe people? I guess it didn't concern me much back then-I only started reflecting on these things later in my life-but I knew then as I know now, this place is special (personal narrative).

My personal narrative begins to explore the 'special' nature of a residential camp. It describes the feeling of entering a space and time that is set aside for fun and friendship. Turner described such experiences as "magical" (1969, p.139) and it is this feeling (magic, belonging, specialness) that I try to capture and convey through my personal narratives. To begin, camps take place in settings that are different from everyday life. Most exist at a physical and social distance from usual and everyday interactions. Turner (1994) refers to the conditions of such separateness and transition as liminality. Liminality is a state where familiarity can be lost, new roles must be negotiated, expectations are challenged, and individuals can experience growth. Liminality makes it possible, if not expected, for participants to experiment with and experience different identities.

Entering a liminal space, like a residential camp, can be disorienting. We know that campers may struggle with new food, new accommodation arrangements, new caregivers, and new friends. Research suggests that campers may experience isolation, loneliness, bullying and homesickness (Carney \& Nottis, 2008; Fichman, Koestner, \& Zuroff, 1997; Thurber, Sigman, Weisz, \& Schmidt, 1999; Wilson \& Sibthorp, 2017). Vulnerability may also emerge as campers are separated from familiar relationships and roles. This condition can be at once frightening and liberating.

While liminality can be difficult, it can also be a source of considerable growth. With guidance from counsellors, campers can discover and bask in new roles and increased capacities (Henderson et al., 2006). Unsurprisingly, community created within liminal space can be socially significant (Bruster \& Weimann, 2004). The challenge, though, is the potentially inordinate amount of pressure placed on counsellors as campers negotiate complexity and discomfort in liminal space. Camp counsellors are responsible for the everyday care, self-development, recreation, and safety of campers for days and weeks on end (American Camping Association, 1993; Meier \& Mitchell, 1993). These responsibilities can create unusual pressures on youthful employees. 


\section{Welcome to the Bubble}

Yet we know little of the counsellor experience within residential camp settings. They, too, exist within liminal space where social norms are altered. They are expected to help create the magic that camps promise while they themselves are faced with difficulties, both practical and personal. This study seeks to better understand the challenges faced by camp counsellors so that we can better support their efforts.

\section{Review of Literature}

\section{Residential Camps and Liminality}

Residential camps offer a physical, social, and even emotional break from campers' own communities, homes, and relationships. Natural features of camps (e.g., long gravel driveways, access via boats, surrounding forests) draw boundaries around camp time and space (PrestonWhyte, 2004; Weber, 1995). In this way, camp experiences exist within a liminal space. Liminality exists when everyday routines, rituals, and spaces are altered or abandoned in meaningful ways (Turner, 1994). Liminality, and the social cohesion generated within it, provide opportunities for individuals to experience ideal, albeit utopian, community living as well as their individual value in belonging to this community (Olaveson, 2001). These experiences can be profound and encourage individuals to readjust and/or recreate their values (Olaveson, 2001). Turner saw these experiences as akin to spiritual rebirth (Olaveson, 2001).

The social and physical seclusion of camps create a space that provides the anti-structure necessary to form what Turner calls a status of "betwixt and between" (1994, p. 8). Camp spaces form a sort of "bubble" away from campers' and staff members' everyday lives wherein reality is suspended. Within this new reality, new ways of thinking and acting can emerge. Roles and statuses can change. Perceptions of equality develop as individuals are reduced to a human common denominator within liminal spaces (Turner, 1982). That is, the roles and status of our ordinary lives (job position, academic performance, family hierarchy) hold less relevance to who we are in a liminal space.

Substantial research exists on the benefits of camper experiences (Chenery, 1993; Dorian, 1994; Ewert \& Yoshino, 2011; Gustafsson, Szczepanski, Nelson, \& Gustafsson, 2012; Henderson \& Bialeschki, 1999; Henderson, et al., 2006-2007; Henderson et al., 2006; Holman \& McAvoy, 2003; Williams, 2013). The special qualities of camp relationships, and consequently camp community, have often been associated with positive personal, emotional and social 


\section{Welcome to the Bubble}

development (Bialeschki, Henderson, \& Dahowski, 1998; Glover, Chapeskie, Mock, Mannell, \& Feldberg, 2013; Henderson et al., 2006).

The literature is less complete for camp counsellor experiences and specifically, the challenges they face in living and working within camp liminality. Much like campers, camp counsellors may also be disoriented by the differences of camp. While at home they may be described as sons and daughters, as students, or as residents of familiar and comfortable neighborhoods. In the altered context provided by camp, these young counsellors are often considered mentors, teachers, safety personnel, and even emotional support workers (Ross, 2009). In camp, they must, by necessity, create new and important identities. Allen (2004) suggested that individuals, such as camp counsellors, are "embodied, embedded in a social and cultural milieu" and "constituted by power relations" (p. 235). Camp counsellors must contend with and navigate multiple, messy and even contradictory messages about what and who they are and are meant to be within camp contexts. This additional dimension to working in liminal space can be demanding, distressing, daunting, and disorienting.

The study described in this paper examined the embodied experiences of camp liminality from the perspective of 38 in-depth interviews with a variety of residential summer camp counsellors. Their camp experiences are constructed by many discourses, some of them competing, and all can be profound. The purpose was to better understand the complexity and challenges of living and working within camps.

\section{Campers and Communitas}

Individuals in liminal communities tend to engage with one another in direct, sympathetic, and non-judgmental ways (Turner, 1982). The usual assumptions made in relation to a person's role, status, reputation, class/caste, sex, or other structural niche tend to fall away and, rather, individuals are addressed in terms of their value to the "here-and-now" (Turner, 1982, p. 48). These conditions help create what Turner and others (Andrews, 1999; Côté-Arsenault, Brody, \& Dombeck, 2009; Sharpe, 2005) call "communitas" (Turner, 1969, p. xvi). Sharpe argues that "communitas emerges when people step out of their structural roles and obligations, and into a sphere that is decidedly 'anti-structural' ....and the rules of everyday life can be altered, inverted and made topsy-turvy" (2005, p. 256). Experiences of communitas are characterized by "feelings of equality, linkage, belonging, and group devotion to a transcendent goal" (Arnould \& Price, 1993, p. 34). When communitas exists, participants place high value on personal honesty, openness, and lack of pretentions or pretentiousness (Turner, 1982). 


\section{Welcome to the Bubble}

Camp community living represents, in many powerful ways, Turner's description of communitas (1982). For example, feelings of belonging and inclusion are among the highest priority for camp counsellors to deliver and manage for those campers in their care (Ross, 2009). Liminal spaces are defined by the collective investment of all participants in singular or focused goals (Sharpe, 2005). Within camps these goals appear to be ideals of fun, belonging, and character development. This would suggest that, within camps, individuals are judged on the degree to which they contribute to this sense of communitas. While usual markers of identity (sex, race, status) do not disappear (and likely play roles in camp communities), camp communitas provides a unique time and space for altered and idyllic social norms. Not surprisingly, the camp community is seen as one of the most outstanding and positive aspects of working at summer camp (Meier \& Mitchell, 1993; Ross, 2009).

The role of the counsellor seems central to the ongoing delivery of the camp promise (i.e., fun, belonging, positive character development). The management of ongoing interpersonal dynamics are largely assigned to young summer camp counsellors. Yet very few studies exist that consider the experiences of camp counsellors as they fulfill their many roles within camp settings.

\section{The Camp Counsellor}

Bialeschki et al. (1998) conducted one of the few studies on camp counsellors. They sought to explore the perceived benefits associated with summer camp staff experiences. An analysis of the positive outcomes suggested that camp staff benefited by making friends, learning about diversity, developing teamwork skills, and experiencing personal growth (Bialeschki et al., 1998). However, the study identified concerns over fundamental working conditions in camp settings. For example, those counsellors interviewed felt that they deserved higher wages and more privacy in light of the level of responsibility and intensity of effort that was required of them (Bialeschki et al., 1998). They reported that part of the concern also related to being acknowledged for the hard work done. Overall, the staff felt undervalued. The findings of this study suggested that industry practitioners and researchers alike have much to gain from examining the experiences of camp staff and how best to support them. However, the issues may run deeper than wages and privacy. The complexity and intensity of residential camps can challenge and disrupt. According to Olaveson, "a very intense social life always does a sort of violence to the individual's body and mind and disrupts their normal functioning. This is why it can last for only a limited time" (2001, p.100). The stripping away of familiar roles and statuses 


\section{Welcome to the Bubble}

necessary for anti-structural reality, in which communitas may emerge, can make camp employees vulnerable.

While vulnerable, camp counsellors are immersed in the production and support of camp liminality for days and weeks on end. During that time, they are responsible for the everyday care and safety of campers in their charge (American Camping Association, 1993; Meier \& Mitchell, 1993). Camp managers call on counsellors to act as a camper's friend, parent, therapist, and teacher (Ross, 2009). Camp counsellors, not much older than campers (16-25 years old) themselves, are expected to facilitate personalized opportunities for campers to gain skills and improve self-concepts through positive and meaningful camp experiences.

Within this context, this article seeks to explore the formation of liminality and the emergence of communitas for camp counsellors. How do counsellors experience their many roles within the liminal space offered by residential camps? Insights were gathered from camp counsellors' own reflections of the processes and outcomes that characterize the residential camp experience. These reflections were used to identify key issues within the counselling process and the challenges camp counsellors' faced in living and working in camp liminality.

\section{Research Design}

This qualitative study draws on research materials from 38 in-depth interviews with camp counsellors. These were woven together to create a narrative that reflects at least part of the counsellor story. Several sampling techniques (convenience, purposive, and snowball) (Neuman, 2006) were used to generate a pool of interview participants. Interview participants were selected with particular attention to diversity among demographic characteristics, amount of time worked at camps and time since their last employment experience.

Interview participants had worked a minimum of one summer (approximately two months on a seasonal contract) upwards to "many years" in full-time camp employment. The greatest number of interview participants had three years camp counsellor experience (16\%), followed by one and five years ( $13 \%$ each). Interview participants ranged from current employees (18\%, usually full-time) or having just finished work two months prior (47\%) to $10+$ years since they worked at camp (8\%). Interview participants were 17 to 59 years old with the majority of interview participants 19 to 24 years old ( $40 \%)$ followed by $25-29$ years old $(21 \%)$. The majority of interview participants were female (63\%). Interview participants were well educated and held undergraduate degrees (38\%) or postgraduate degrees $(29 \%)$. 


\section{Welcome to the Bubble}

I conducted interviews across southwestern Ontario, Canada using a semi-structured interview guide over a 1-month period. The interviews were digitally recorded. Interviews were transcribed and manually coded at an initial stage and then again using NVivo 10 software to manage the large volume of text. I analysed the research materials for initial themes (camp rituals or the development of community) as well as discursive practices (how liminality was articulated through particular statements). Discursive analysis was employed as a complementary approach (Symon \& Cassell, 2012). In particular, I concentrated on the emotional language and metaphors used to articulate the experiences of living and working within the camp context.

This study was conducted by pairing a modified grounded theory method and reflexive methodology. Grounded theory methods offer "systematic, yet flexible guidelines for collecting and analysing qualitative data" that "construct theories 'grounded' in the data themselves" (Charmaz, 2006, p. 2). That is, I looked for commonalities to produce themes among the participants' narratives as well as unusual stories. However, my grounded theory was modified, as I did not seek to generate theories or assume I held some superior authority on the matter. Instead I drew on a reflexive methodology to call into question my own interpretation, and that of others, of the meaning of camp counsellors' experiences. Reflexive methodology suggests an approach that recognizes a multiplicity of influences in the meaning making of the research process (Alvesson \& Skoldberg, 2000). Additionally, reflexive methodology draws attention to the contribution of the researcher's dialogue with the research subject, literature, research participants, herself and the reader in "the process of research and in the (final) textual product" (Alvesson \& Skoldberg, 2000, p. 249).

While much of this process is not evident in the discussion that follows, the questioning of the construction of knowledge was implicit to the production of this study. I chose to present the following discussion in a more traditional format with critical and creative inclusions (i.e., personal narratives). A reflexive methodology has not only been beneficial but necessary throughout the research process as I attempted to weave many texts together into a coherent multivoiced research narrative while staying critical and accountable to the various perspectives that informed my study of camp counsellor experiences of liminality and communitas. Charmaz argues that grounded theory methods can "complement other approaches to qualitative data analysis" and that is why they "continue to appeal to qualitative researchers with varied theoretical and substantive interests" (2006, p.9). Ultimately, "when combined with insight and 


\section{Welcome to the Bubble}

industry, grounded theory methods offer sharp tools for generating, mining and making sense of data" (Charmaz 2006, p.15).

I begin the results with a personal narrative. Through this narrative I seek to situate the reader within the liminal space offered by a typical residential camp.

\section{Welcome to the Bubble}

And now the driveway, the very long driveway, climbs over the landscape and down into the main campsite. It's a steep hill down and up and down again. The pond is on the right, then the director's house is on the left, which is followed by the field (where we played sponge wars), and then the little pool, and-oh! The freezing rush of early morning polar bear dips comes over me just thinking about that pool. On the right, as you come into the main area, are the camp office and dining hall; homemade macaroni and cheese (a mealtime staple) is still my favorite. I can stand on the spot there, in the parking lot, and turn and "camp" is all around me; the surrounding green of grass, lakes, and trees, the cold pool water on my skin, the smells from the kitchen, and the sounds of happiness in the air (personal narrative).

I use this narrative to introduce what many interview participants referred to as "the bubble." To many participants, the term was obvious, common, and normal parlance of camp folk. When camp people speak about the bubble, they are referring to camp being a physically and socially exclusive place apart from their real lives, or rather, the lives they lead outside of camp. Camp counsellors even talked about their non-camp lives as "the real world," illustrating how camp is somehow perceived to a degree of fantasy or fiction. For example, Andy commented, "You literally live in a little bubble. I mean you really don't hear anything that's going on in the outside world." The following sections will discuss the formation, benefits, and challenges of camp communitas for camp counsellors. The camp bubble is such a unique experience that Terri said, "those who are inside it [camp] can't explain it, and those who are outside it can't understand it." For those of you unfamiliar with camp or those intimate with it, I'd like to welcome you (back) to the bubble!

\section{Camp Liminality and Communitas}

And that's sort of where the driveway ends and the rest of the camp takes over. That funny little shack that's inscribed with my cousin's name and the woods . . . what was 


\section{Welcome to the Bubble}

it called again? Something romantic, like Beech hollow or Oak valley. It's where the kitchen staff used to eat lunch. Then staff quarters for those who didn't have a cabin with kids. The toilet and shower block. Then "the horseshoe, "with little cabins ringing the edges, nestled neatly into the forest. The craft shack and a set of swings sits in the middle. In my childhood, I believe, there was other play equipment in the middle too (personal narrative).

The bubble occupies physical space that is signified by the natural geography of campsites and their surroundings. Elements such as gates, signs, gravel driveways, and tree-lined avenues demarcate the borderlines of camp liminal space (Preston-Whyte, 2004; Weber, 1995). The trees, for example, separate camp and reinforce the geographic isolation of camp from the outside world. Yet it is the meanings that are attributed to these natural features that help to create an ephemeral and liminal sphere around camp space and time. Romantic notions of pure nature and rural idyll pervaded accounts of camp experiences. For example, Tess recounted a love of "lying out on the dock in the middle of the night watching the stars with friends." Henry described the joy of playing in mud puddles and the spontaneity of weather-dependent activities.

Rebecca and Lisa both reflected on moments in the shade of great trees. Childlike awe and appreciation existed in the interviewees' statements about the intrinsic beauty of the natural environments of their camps. Each one drew on special memories of the natural environment such as trees, rivers, rocks, lakes, and woods. The wonder-making of nature in camp experiences adds to the "dreamtime" of its liminality (Preston-Whyte, 2004). The physical elements and discourses of nature work to reinforce participants' sense of camp being in a unique liminal space while bolstering their desire to stay and participate.

The allocation of physical structures, or camp space, also adds to the construction of liminal camp experiences. As Hall (1959) states, "space speaks" (p. 147). The physical layout of buildings is crucial in developing a context within which altered expectations emerge (Edwards, 1998). The horseshoe of cabins described in the preceding personal narrative is an example of how buildings were organized in ways to reinforce inclusion and belonging to the camp community. Camps' close living quarters also contributed to the establishment of relationships. Counsellors shared living quarters with eight to 10 campers and up to two other camp counsellors. While this situation can be challenging, camp accommodation helped to form strong bonds. April said: 


\section{Welcome to the Bubble}

We just know each other inside and out-you know them so well. And it's on a different level than if you went to school with them. You're living in contact with this person for 24/7 and even though it may only be for 4 weeks out of the year, you know that person. You really, really know that person.

The resulting investment of camp participants in the communal aspect of camp life gives rise to intense passions and emotions and by "bring[ing] all those who share them into a more intimate and more dynamic relationship" (Olaveson, 2001, p.94). Andy echoes this notion about camp community: "You live, breath, eat together, you do everything together" so campers and counsellors "form bonds and you have good memories." By being together at camp, the relationships typical of communitas were formed.

Camp participants were encouraged by the geographical and social isolation of camp experiences to step outside their structural roles and obligations (Sharpe, 2005) and invest in the camp community. Several interviewees suggested that personal communication devices, which have become mainstays of youth experiences, were often banned in the hopes of creating more cohesion among camp counsellors. Unplugging from one's multifarious and fast-paced life was desired as a means of investing fully in camp relationships. The liminality of camp space and time, including the limitations of contact with home, contributed to the possibility of experiencing communitas. David reinforced that the isolation from the news of the world (personal and global) intensified the camp experience, because there was little broader information to hinge one's perspectives of reality on: "Like Canada could be invaded and we would have no idea . . . unless somebody called." Camp participants build relationships with one another in the interest of experiencing community and in the absence of other, more familiar, relations. Many interviewees stated that camp was seen as an opportunity to make deep social connections and was about "that sort of opportunity to connect with other people who are like you" (Terri). Trudy viewed camp as primarily an opportunity to "make deep connections with people that really matter" and who "understand you and accept you." The limitations and regulation of contact with home contributed to the power and benefits of experiencing camp communitas.

\section{Belonging and Acceptance - The "Feel" of Communitas}

The whole site was filled with sound. Birds and insects? Yes, but the air was perforated with children laughing and yelling and having a great time. You could be noisy at camp. In fact, being noisy made you king! If you could sing loudly or shout 


\section{Welcome to the Bubble}

with enthusiasm then you belonged to the musical and social fabric of this world. And songs ... we sang all the time. We sang to wake and eat and wait and walk and play and sleep. The constellations of sounds that engulfed us at camp were heady and giddy at times, soothing and reassuring at others. Music set the rhythm and pace of the day (personal narrative).

Belonging was one of the most pervasive responses about the benefits of camp communitas. The strong emotional connections with others, such as "that really strong connect of friends at camp" (April), was unanimously described as positive. Rebecca saw the objective of camp as "building community, even for a short period of time, with new people" and "definitely about making new friends." Belonging and acceptance were highly prioritized social objectives and an important aspect for all camp counsellors, regardless of camp hierarchy and staffing structures. Many staff described that relationships at camp were accelerated, positive, and intensified by simply being at camp. In fact, Olaveson described the relationships of communitas to be:

. . . an exceptionally powerful stimulant. Once the individuals are gathered together, a sort of electricity is generated from their closeness and quickly launches them to an extraordinary height of exaltations. Every emotion expressed resonates without interference in consciousness that are wide open to external impressions, each one echoing the others (2001, p. 99).

The harmonious and unfettered nature of relationships within this context was an expected and accepted outcome of living in a utopian-like community as described by several counselors. Singing, such as that described in the narrative above, helped to reinforce belonging. For example, Lisa said she always enjoyed the singing at morning circle, because it would bring "the whole camp together." Even the friendship bracelets made and steadfastly worn at camp were powerful reminders of one's social connection and belonging to camp. The belonging of camp communitas can be an emotionally powerful experience.

There is also rich potential inherent in liminal periods for an emergent sense of freedom. Such freedom can be intoxicating and can contribute to spiritual rebirth, transformation, and recuperation (Preston-Whyte, 2004). April's account most typified the genre of life-changing narratives that were commonly told about summer camp experiences:

This is a wonderful story. I'm not going to do it justice. You would have to see the transformation yourself. We had a boy that . . . had a whole range of learning disabilities... And he came as the most unstable - he was a mess. He was really a mess. And then 


\section{Welcome to the Bubble}

we worked hard with him for a month. . . . he just completely transformed. It's like it [camp] had gotten rid of his problems. ... I think camp saved him.

Most transformation narratives told by interview participants were about their campers. Camp counsellors were positioned and felt responsible for the positive transformation of campers in their care. Camp counsellors were expected to influence the transformation of campers. Eric illustrated how he viewed his role in the positive self-transformation of his campers:

... seeing a real positive change . . . it just makes you feel that much better about helping these kids because you're a positive value to them. And I really felt that was the biggest highlight-just helping these kids realize they can do so much in the world.

Eric identified the benefits of his role as being of "positive value to them." Camp counsellors appeared to take up the responsibility to improve or transform campers, as April explained: "you're trying to change these kids' lives." Stories that recount the improvement, if not transformation, of camp selves is pervasive in camp texts (e.g., popular culture, research, camp marketing). Camp discourses about the transformative self suggests that campers and camp counsellors have a will to change in profound ways due to camp experiences.

\section{Challenges Faced by Camp Counsellors}

Communitas in camp environments happened out of necessity to a certain degree. Given the relative isolation from familiar supportive relationships, staff mentioned that making new friends was essential and needed to be done quickly. Developing friendships came easier for some staff than for others. Matthew, for example said, "I'm shy, so camp wasn't that fun for me. I wasn't outgoing enough to be a favorite." There was immense pressure to fit in, make friends, and belong in new camp environments for both camp counsellors and campers. For example, Steph revealed:

I don't like the first day. You know, when everyone gets to know you; it's so crucial. I guess I'm just one of those people who is shy ... I always feel for the kids the first night. You know, they show up and they just want to be accepted into the group, they want to be treated well, and they've had this experience built up for them by all the people who've already done it . . . "You'll love it, these are going to be the people you'll make friends with for the rest of your life, "and just the pressure of that. 


\section{Welcome to the Bubble}

Camp counsellors often felt responsible for campers' experience of belonging at camp even when this experience was not always possible or within their control. Staff noticed that experiences of social isolation or ostracism were exaggerated in an environment like camp. For staff, in particular, Trudy suggested that camp's social life often relied on "a real in-group" and, while some outsiders "have succeeded," not everybody feels like they belong to the same degree. Youthful camp counsellors were required to negotiate their own feelings of vulnerability, friendship and belonging while ensuring that their campers' experiences were positive.

The social isolation of camp reinforces the exclusive and community-centric nature of camp relationships. Some interview participants described camp relationships as being consuming and, consequently, the social camp environment was intense in negative ways. These statements referred to a kind of pressure that they felt about being expected to be close to or connected with everyone (at all times) in the camp community. For example, Andy said:

It's almost like, at camp, you have to know everything that's going on ... Even among the staff there's a little clique here and a clique there and you're like "Ah what's going on?" and "Who's doing what on their days off?"

Tom confirms "there are no real secrets at camp. Usually if a few people know something, then everyone knows." Numerous interview participants agreed that "camp community has such rampant gossip" (Beth) and, for the most part, this fact was seen as unavoidable within camp communities. In Devon's camp, staff would regularly update camp gossip through all-camp skits that thinly disguised the identity of the person(s) involved. With so few opportunities for private space and time, even the most mundane or intimate details of a camp counsellor's life could become public entertainment for the entire camp community. Even with the best intentions, camp communitas does not always embody all its intended virtues.

Other pressures reported about camp counsellor social life included being constantly observed by campers and other staff. The continuous peer evaluation of camp counsellors also meant that an individual's work ethic and work load were a point of contention and complaint such as "he's not working as hard as I am or she's not pulling her weight" (Tom). The pressure created by camp liminality meant that behaviors that "would be a non-issue" outside of camp would "get on peoples' nerves" as the summer wore on (Elissa). Complaints like "you didn't keep your campers quiet," "I saw you take an extra piece of garlic bread at lunch" or "I heard that you went to the movies and didn't invite me" (Elissa) demonstrated that even the smallest acts could cause irritation. More than that, isolation ensured that camp counsellors and campers alike could never 


\section{Welcome to the Bubble}

truly escape issues and challenges. Both David and Beth talked about how, at camp, it was easy to make too much of something small:

I think that a huge part is the fact that the camp community is usually in a residential setting, such a closed community, that things that wouldn't be issues in other professions get magnified because it's such a tiny environment. . . I think in most professions you go home, have dinner, go to a movie, talk to your friends and come back the next day and have a fresh perspective but at camp, you stew about it and you get worried about it and it builds. (Beth)

With little time or options to be away from one another, summer camps became a social pressure cooker for the staff that remained on site all summer.

The isolation of camp liminality created a socio-relational vacuum where campers looked to camp counsellors to fill the absences of familiar relationships. Camp counsellors were asked to play the roles of parent, brother/sister, friend, teacher, and mentor to the campers in their care. Ross's camp counsellor textbook includes six chapters titled "The Counsellor as...the Leader, the Member of the Staff Team, the Teacher, the Disciplinarian, and the Risk and Crisis Manager" (2009, p. vii-viii). Camp counsellors in this study said they were not only expected to play these complex roles but must perform them with maturity, judgement, awareness, and responsibility. Sophie also added "being really positive" and Tom added "hard work" as a "personality thing" to the list of leadership qualities. Grant recalled a sense of awe for camp counsellors: "I think when you're a camper, you sort of have a vision of them being almost like a god." Being a camp counsellor, according to these accounts, was a lofty task and required near godliness.

The 24/7 nature of camp was mentioned by many of the interviewees. This condition required that camp counsellors were always "on," thus creating pressures for them to selflessly and tirelessly care for campers in a continuous positive and fun manner. The emotional demands on camp counsellors, such as caring, nurturing, being a parent and friend to campers, was largely invisible and taken for granted. Yet there was no denying that the emotional demands placed on camp counsellors were real as evidenced by Zoey's powerful comments:

That was probably when I hit a wall, there's too much emotion and I'm too invested . . . . I think if you are going to do a good job, you are going to care. That doesn't necessarily mean you need to bawl your eyes out for an hour when you are sad, but I think that is valid. . . I think that's probably the only time that 
Welcome to the Bubble

there's been a huge wall of me being so exhausted emotionally and physically.

Andy and Terri both commented on the fatigue and exhaustion of camp counsellors. Terri described the challenge to stay "happy" when she felt worn out as her summer employment progressed:

... like stretching every last ounce of anything you have, so you become short, and that's not who you want to be, but it's all you have. You feel so bad for it, but you also need to realize that it's natural, and you shouldn't be expected to be happy-go-lucky, like that's not fair either, I don't think.

Terri felt guilty for not being happy when she was tired, and Elissa suggested that the "happy bubble" that people call camp is, in fact, "a fragile bubble, and it can burst so easily."

While I acknowledge the power of liminality in the camp experience, I also wish to acknowledge the toll these experiences can exact from camp counsellors. The very separateness of camp experiences was both a great benefit and a great burden. These data suggested the importance of exploring camp counsellors' experiences of living in and delivering camp communitas.

\section{Conclusions and Implications}

The intensity of summer camp's social community raises questions about camp counsellors' opportunities for personal time and self-care within camp contexts. The emotional demands placed on camp counsellors have implications for the mental wellbeing of staff. Camp owners and managers should consider significant steps to support and care for camp counsellors. By doing so, these counsellors can, in turn, offer better care for campers. Failing to care for counsellors may jeopardize not only the wellbeing of the camp workforce but also jeopardize staff capacity to deliver camp.

\section{(Re)Framing Camp Counsellors}

I invite readers to (re)frame their understanding of camp counsellors. I wish to start by disrupting assumptions about the unitary nature of experience and subjectivity (Weedon, 2004) and recognize that individuals are complex. Camp counsellors' perceptions, experiences, and responses can be dynamic, messy, and even contradictory (Wearing, 1998). Additionally, camp counsellors work within a complex network of relationships (Marshall, 1997). Camp counsellors 


\section{Welcome to the Bubble}

must navigate relations that include campers, parents, peers, and managers as well as practices, policies, historical influences, and governing systems that are often invisible. Camp counsellor experiences are shaped through interactions with multiple sources of diverse, often invisible but influential, relationships of power and camp discourses.

Camp counsellors must find support in people they have only just met and who are also embedded in the same complex social reality as they are. Moreover, expectations that everyone will belong and experience personal growth as a result of camp experiences put immense pressures on camp counsellors to deliver with little consideration of how they will cope. This study suggests that camp researchers, industry leaders, and camp managers should seek greater understanding of the dynamics surrounding counsellors and camp liminality. Specifically, they would benefit from better understanding the emotional demands the delivery of communitas places on camp counsellors. Most importantly, this study raises awareness of the pressures created as counsellors attempt to create camp communitas.

\section{Implications for Practitioners}

The liminality and communitas of camp can provide significant benefits to both campers and camp counsellors. Camps offer a wide variety of measures that help build and maintain that communitas. Staff may benefit from efforts that help them feel like they belong in the camp culture. Practices that help nurture this feeling include the availability of camp merchandise, clothing or uniforms; camp photos; staff social events; rituals like mealtime announcements or campfire; staff contracts and manuals; mentorships; staff encouragement activities (i.e. warm fuzzies), and daily staff meetings. As discussed in this article, physical aspects such as isolated geographies (e.g., rural, forested or water-only access), reduced contact with friends and family outside of camp (such as limited internet access), and building placement ('U' or circle shaped) can contribute to a sense that camp space is special. While these measures are helpful, they may be dwarfed by the roles played by counsellors. Counsellors put a human face on camp experiences. Camp managers are very much aware of this and seek to hire people who exhibit particular personality traits (e.g., outgoing, high energy, friendly, altruistic).

More than that, camp managers may seek to develop the skills and talents of those on staff. One camp director in this study spoke of the extensive leadership development programs and alumni networks that helped to maintain the camp's culture from season to season and year to year. While some of these practices appear to be small and/or unintentional, it is often the everyday practices that influence behavior-particularly within liminal spaces where a lack of 


\section{Welcome to the Bubble}

other influences can distract participants. When all staff have a clear objective for the delivery of camper experiences (fun, belonging, and personal growth) then the aspects (great or small) of a camper's experiences will likely align.

Camp counsellors face many of the same challenges as campers in becoming oriented in the new social reality that camp liminality creates (new friends, new identities, new roles and statuses). However, they face additional challenges. They are under pressure to perform many complex roles of care (parent, sibling, friend, teacher, mentor, risk manager). They are expected to fulfill these roles through displays or even embodiment of happiness, positivity, genuine care, and fun, with few opportunities for rest or renewal away from campers (and even less from peers). Consequently, the effects of the emotional demands placed on camp counsellors can be significant.

Practitioners have a significant responsibility to ensure youth employment experiences are healthy and appropriate. They must engage reflexively with the practices and discourses that shape camp counsellors' experiences of liminality and communitas. For example, camp counsellors feel pressure to change the lives of campers despite their own youth and inexperience. This expectation suggests that camp counsellors require a good deal of training, guidance, and support in their employment roles. Everyday employment practices of youth and young adults needs to encourage reasonable expectations for development, boundaries, private time and space as well as adequate emotional rest. Some practical solutions to these challenges, revealed through the broader study from which this paper is drawn, suggested inverted staffing structures where the most youthful staff perform planning and logistic roles with the most experienced staff performing contact roles (i.e., camp counsellors). Another option is to schedule a revolving staff roster where each employee is offered a contract shorter than the season (e.g., six out of an eight-week summer), ensuring that every staff member gains sufficient rest and private time away from the site. While no single or universal solution exists, there is a need for engagement with more research, dialogue and self-reflective practices to work toward ethically addressing and supporting youth employment and the delivery of extraordinary community experiences.

Future research would benefit from exploring the emotional demands that the delivery of communitas place on camp counsellors. The findings from a study of this nature could lead to better employment practices that support the growth and performance of youthful camp staff. A need exists for further research into the employment practices that best support the complex and challenging work of camp counsellors. Better understanding of camp counsellor experiences 
Journal of Youth Development | http://jyd.pitt.edu/ | Vol. 13 Issue 1-2 DOI 10.5195/jyd.2018.565

Welcome to the Bubble

could lead to more thoughtful, engaged and reflexive strategies to support employees in delivering camp communitas to all those within "the bubble."

\section{References}

Allen, A. (2004). Foucault, feminism, and the self: The politics of personal transformation. In D. Taylor \& K. Vintges (Eds.), Feminism and the final Foucault (pp. 235-257). Chicago: University of Illinois Press.

Alvesson, M., \& Skoldberg, K. (2000). On reflexive interpretation. Reflexive methodology(pp.238-292). London: SAGE.

American Camping Association. (1993). Standards for day and resident camps: The accreditation program of the American Camping Association. Martinsville, IN: American Camping Association.

Andrews, K. (1999). The wilderness expedition as a rite of passage: Meaning and process in experiential education. The Journal of Experiential Education, 22(1), 35-43.

Arnould, E., \& Price, L. (1993). River magic: Extraordinary experience and the extended service encounter. Journal of Consumer Research, 24-45.

Bialeschki, M. D., Henderson, K., \& Dahowski, K. (1998). Camp gives staff a world of good. The Camping Magazine, 71(4), 27-32.

Bruster, D., \& Weimann, R. (2004). Prologues to Shakespeare's theatre. Performance and liminality in early modern drama. London, England: Routledge.

Charmaz, K. (2006). Constructing grounded theory: A practical guide through qualitative analysis. London: Sage.

Carney, A., \& Nottis, K. (2008). No vacation from bullying: A summer camp intervention pilot study. Education, 129(1), 163-184.

Chenery, M. (1993). Explaining the value of camping. Paper presented at the Annual Conference of the Camping Association of Victoria, LaTrobe University, Victoria, Australia.

Côté-Arsenault, D., Brody, D., \& Dombeck, M. (2009). Pregnancy as a rite of passage: Liminality, rituals and communitas. Journal of Prenatal \& Perinatal Psychology \& Health, 24(2), 69.

Dorian, A. (1994). The effect of a camp experience on self esteem. Evaluation/ Feasibility (pp. 1-8): Ursinus College.

Edwards, S. (1998). An anthropological interpretation of nurses' and patients' perceptions of the use of space and touch. Journal of Advanced Nursing, 28(4), 809-817.

Ewert, A., \& Yoshino, A. (2011). The influence of short-term adventure-based experiences on levels of resilience. Journal of Adventure Education and Outdoor Learning, 11(1), 35-50. 
Journal of Youth Development | http://jyd.pitt.edu/ | Vol. 13 Issue 1-2 DOI 10.5195/jyd.2018.565

Welcome to the Bubble

Fichman, L., Koestner, R., \& Zuroff, D. (1997). Dependency and distress at summer camp. Journal of Youth and Adolescence, 26(2), 217-232.

Glover, T. D., Chapeskie, A., Mock, S. E., Mannell, R. C., \& Feldberg, H. (2011). The Canadian summer camp research project: examining the outcomes of the Canadian summer camp experience. Waterloo, ON: University of Waterloo. Retrieved from: http://www.ahs.uwaterloo.ca/ tdglover/PDF\% 20Files/CSCRP, 202011, 27-46.

Gustafsson, P., Szczepanski, A., Nelson, N., \& Gustafsson, P. (2012). Effects of an outdoor education intervention on the mental health of schoolchildren. Journal of Adventure Education \& Outdoor Learning, 12(1), 63-79.

Hall, E. (1959). Space speaks (from the silent language). Landmarks of American language and linguistics, 1, 147-157.

Henderson, K., \& Bialeschki, M. D. (1999). Camping and social capital. Camping Magazine, 72(6), 46-47.

Henderson, K., Bialeschki, M. D., Scanlin, M., Thurber, C., Whitaker, L., \& Marsh, P. (2006-2007). Components of camp experiences for positive youth development. Journal of Youth Development, $1(3), 1-22$.

Henderson, K., Thurber, C., Schuler Whitaker, L., Bialeschki, M. D., \& Scanlin, M. (2006). Development and application of a camper growth index for youth. The Journal of Experiential Education, 29(1), $1-17$.

Holman, T., \& McAvoy, L. (2003). Outcomes, consequences and values of an integrated wilderness adventure program. The Journal of Experiential Education, 25(3), 353.

Marshall, J. (1997). Michel Foucault: Problematising the individual and constituting 'the' self. Educational Philosophy and Theory, 29(1), 32-49.

Meier, J., \& Mitchell, A. (1993). Camp counseling: leadership and programming for the organized camp (7th ed.). Madison, WI: WCB Brown \& Benchmark.

Neuman, W. (2006). Social research methods: Qualitative and quantitative approaches (6th ed.). Boston, MA: Allyn and Bacon.

Olaveson, T. (2001). Collective effervescence and communitas: Processual models of ritual and society in Emile Durkheim and Victor Turner. Dialectical Anthropology, 26(2), 89-124.

Preston-Whyte, R. (2004). The beach as a liminal space. A companion to tourism (pp. 349-359).

Ross, C. (2009). How to be a camp counsellor: The best job in the world! Toronto, ON: Ontario Camps Association.

Sharpe, E. (2005). Delivering communitas: Wilderness adventure and the making of community. Journal of Leisure Research, 373), 255-280.

Symon, G., \& Cassell, C. (2012). Qualitative organizational research: Core methods and current challenges. Thousand Oaks, CA: Sage. 
Welcome to the Bubble

Thurber, C., Sigman, M., Weisz, J., \& Schmidt, C. (1999). Homesickness in preadolescent and adolescent girls: Risk factors, behavioral correlates, and squelea. Journal of Clinical Child Psychology, 28(2), 185-196.

Turner, V. (1969). The ritual process: Structure and anti-structure. New York, NY: Aldine De Gruyter.

Turner, V. (1982). From ritual to theatre: The human seriousness of play. New York, NY: Performing Arts Journal Publications.

Turner, V. (1994). Betwixt and between: The liminal period in rites of passage. In L. Mahdi, S. Foster, \& M. Little (Eds.), Betwixt and between: Patterns of masculine and feminine initiation (5), 3-19. Peru, IL: Open Court.

Wearing, B. (1998). The self and freedom and constraint in leisure: Interactionist theories. Leisure and Feminist Theory, (pp.38-59). London, UK: Sage.

Weber, D. (1995). From limen to border: A meditation on the legacy of Victor Turner for American cultural studies. American Quarterly, 473), 525-536.

Weedon, C. (2004). Identity and culture. Berkshire, UK: Open University Press.

Williams, R. (2013). Woven into the fabric of experience: Residential adventure education and complexity. Journal of Adventure Education \& Outdoor Learning, 13(2), 107-124.

Wilson, C., \& Sibthorp, J. (2017). The developmental importance of success and failure experiences at summer camp. Journal of Youth Development, 12(3), 18-36. 